\title{
FATIGUE PROPERTIES OF WELD JOINT OF STEEL SHEETS TREATED BY PLASOX PROCESS
}

\author{
Jozef Bárta, Milan Marônek, Jaroslav Jančár, Peter Krampot’ák, František Nový, Ivan Samardžić
}

Original scientific papers

The paper deals with the fatigue properties of weld joints of thin steel sheets DC01 as well as the fatigue properties of weld joints of steel sheets DC01 treated by the PLASOX process, which is patented by RÜBIG company. Fatigue properties of these steel sheets were consequently confronted with the fatigue properties of these materials without weld. Steel sheets were welded by fibre laser TruFiber 400. Fatigue life tests were carried out under bending load with frequency of $20 \mathrm{kHz}$ on ultrasonic fatigue machine KAUP-ZU. On the fractured surfaces the fractographic analysis was carried out to determine the mechanism of rupture. The results proved that plasma nitrooxidation by PLASOX process had a positive effect on fatigue life of weld joints.

Keywords: fatigue properties; laser welding; plasma nitrooxidation

Svojstva zamora materijala zavarenog spoja čeličnih limova obrađenih PLASOX postupkom

Izvorni znanstveni članak

Rad se bavi svojstvima zamora zavarenih spojeva tankih čeličnih limova DC01 kao i svojstvima zamora zavarenih spojeva čeličnih limova DC01 obrađenih PLASOX postupkom, kojeg je patentiralo poduzeće RÜBIG. Svojstva zamora tih čeličnih ploča dosljedno su konfrontirana svojstvima zamora tih materijala bez zavara. Čelični limovi su zavareni laserskim vlaknom TruFiber 400. Probe na zamor materijala provedene su pod opterećenjem zbog savijanja s frekvencijom od $20 \mathrm{kHz}$ na ultrazvučnom stroju KAUP-ZU. Na puknutim površinama provedena je fraktografska analiza kako bi se odredio mehanizam loma. Rezultati su dokazali da je plazma nitrooksidacija postupka PLASOX pozitivno djelovala na vijek trajanja do zamora zavarenih spojeva.

Ključne riječi: plazma nitrooksidacija; svojstva zamora; zavarivanje laserom

\section{Introduction}

The fatigue of materials is a degradation process of irreversible changes in material's properties. It is caused by the cyclic strain, thermal or thermo-mechanical loading with simultaneous effect of other internal or external factors. A field of ultra-high cycle fatigue $\left(10^{7}<\right.$ $N<10^{10}$ cycles) has been for past ten years the centre of interest for research institutes oriented to improvement of a lifetime, safety and reliability of machine parts, or constructions. The time as the main demand factor substantiates the use of equipment working at frequencies about $20 \mathrm{kHz}$. Degradation fatigue process and initiation of fatigue cracks are in close relation to surface and subsurface material properties [3, 8].

Laser welding of thin sheets is a common thing, however welding of these materials showed serious issues related to porosity and consistency of surface layer $[1,4$, $6]$.

Nitrooxidation belongs to the non-conventional methods of steel sheets surface treatment, which consists of surface nitridation and post oxidation. By this process, increase of mechanical properties together with the corrosion resistance can be done [5]. During nitridation the surface of material is saturated by nitrogen responsible for formation of hard nitride layer.

There is very often discussed priority of surface or subsurface initiation with regard to number of cycles (low, high, ultra-high). On the other hand, this is closely linked with material purity on micro level, homogeneity and heterogeneity of material, size and shape of their structural phases as well as the material surface treatment.

By previous results, the higher fatigue life was proved in case of non-welded steel sheets treated by nitrooxidation. However, this type of treated steels has a great potential in industry, so the fatigue life of the weld joints has to be determined $[2,7]$.

\section{Methods}

As a base material for thermo-chemical treatment by PLASOX process, low-carbon deep-drawing steel DC 01 EN 10130-91 with thickness of $1 \mathrm{~mm}$ was used. This type of steel has very good mechanical properties for forming operations and is mainly used in automotive industry. The characteristic chemical composition is referred to in Tab. 1.

Table 1 Characteristic chemical composition of DC01 steel

\begin{tabular}{|c|c|c|c|c|}
\hline $\begin{array}{c}\text { EN } \\
\text { Designation }\end{array}$ & $\begin{array}{c}\mathrm{C} \\
\max \%\end{array}$ & $\begin{array}{c}\mathrm{Mn} \\
\max . \%\end{array}$ & $\begin{array}{c}\mathrm{P} \\
\max \%\end{array}$ & $\begin{array}{c}\mathrm{S} \\
\max \%\end{array}$ \\
\hline DC01 & 0.12 & 0.60 & 0.045 & 0.045 \\
\hline
\end{tabular}

The surface treatment of thin steel sheets by PLASOX process was carried out in RÜBIG Company. PLASOX process consists of two steps. The first step is plasma nitriding in environment rich in nitrogen and the second step is an oxidation in environment rich in oxygen. Due to the low temperature range $\left(480 \div 580{ }^{\circ} \mathrm{C}\right)$ generally applied during this procedure and the gentle cooling in the furnace, minimum distortion was achieved.

Two samples with different nitrooxidation process parameters were analysed. These parameters belong to standard procedure of PLASOX process parameters, but since they are part of RÜBIG company know-how, exact parameters cannot be published. However, the difference between samples PNO2 and PNO4 were in nitridation time, causing the difference in white layer thickness and integrity. Sample marked as PNO2 was prepared with longer nitridation time in comparison to sample PNO4. 


\section{Results}

\subsection{Microstructural analysis}

The thin $\mathrm{Fe}_{2} \mathrm{O}_{3}$ and $\mathrm{Fe}_{3} \mathrm{O}_{4}$ oxide layer of $0.6 \mu \mathrm{m}$ in thickness (Fig. 1) was observed at sample surface and coparticipates on increased corrosion resistance and lower coefficient of friction. The compound layer often known as white layer was adjacent to the oxide layer and composed of $\varepsilon$ a $\gamma^{\prime}$ phases. The thickness of discontinuous white layer in the case of PNO4 sample was approximately $3 \mu \mathrm{m}$ and these samples exhibited good weldability. In order to evaluate the influence of white layer thickness on weldability the $\mathrm{PNO} 2$ samples with continuous white layer of $6 \mu \mathrm{m}$ in thickness were welded (Fig. 1, Fig. 2). This white layer thickness caused several problems during laser beam welding, e.g. excess porosity and sputter. Therefore this sample was not further analysed.

In both cases the diffusion zone formed by ferritic matrix with precipitated needle shaped $\gamma^{\prime}$ nitrides was connected to the white layer. The rest volume of sample was comprised of diffusion zone. The plasma nitrooxidation process caused presence of nitrides in the whole sample's volume.

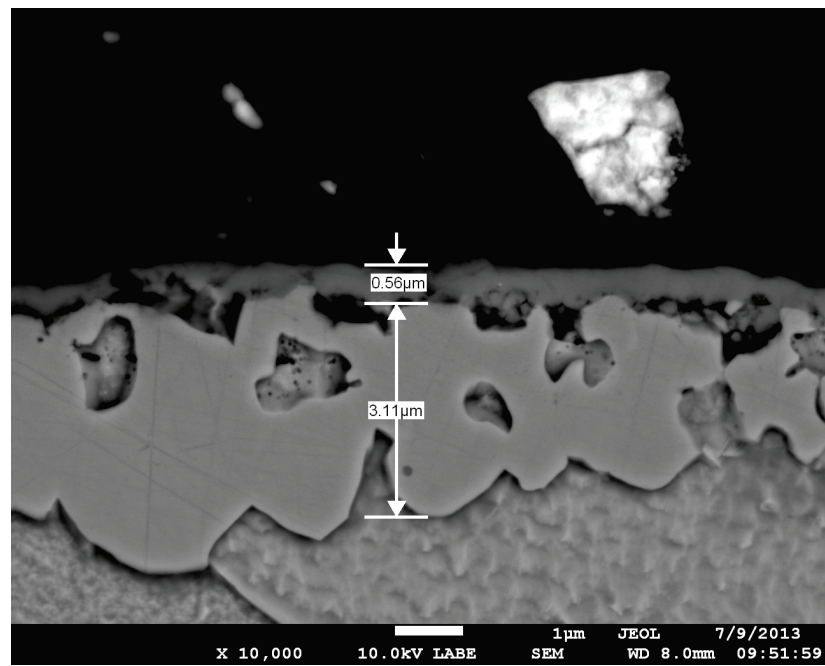

Figure 1 Cross-section of surface layers on sample PNO4

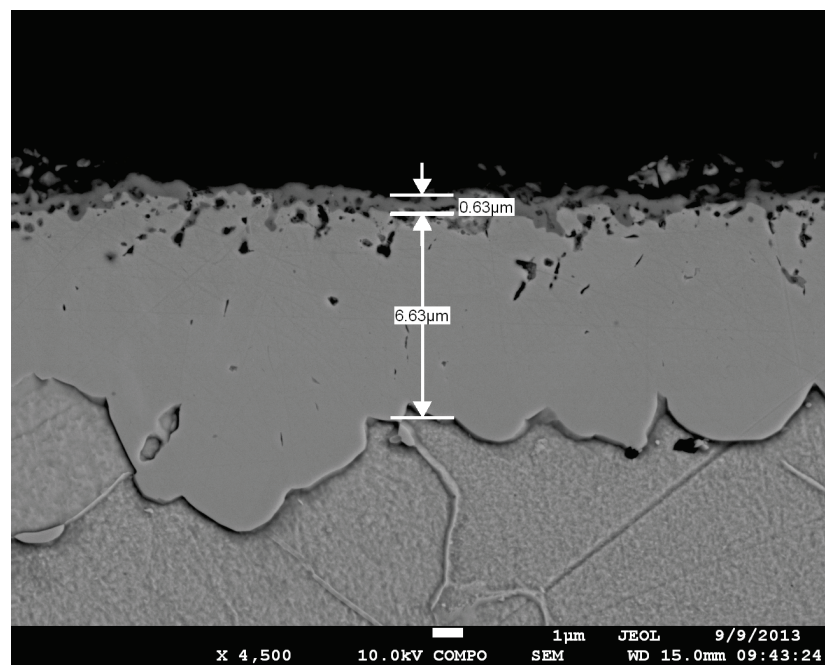

Figure 2 Cross-section of surface layers on sample PNO2

\subsection{Static tensile strength test}

Static tensile strength test was carried out to determine the mechanical properties of steel sheets DC01 before and after the PLASOX process (sample PNO4). The test was performed on three specimens with dimensions of $200 \times 20 \times 1 \mathrm{~mm}$. Values of tensile and yield strength, obtained by test are given in Tab. 2. Mechanical properties of steel sheets after the PLASOX process significantly increased in comparison to DC01 base material. Yield strength of specimens treated by PLASOX process increased by $81,1 \%$ and the tensile strength increased by $54,3 \%$ in comparison to base material.

Table 2 Mechanical properties comparison of material before and after treatment

\begin{tabular}{|c|c|c|c|}
\hline Sample & $\begin{array}{c}\text { Yield strength } \\
(\mathrm{MPa})\end{array}$ & $\begin{array}{c}\text { Tensile strength } \\
(\mathrm{MPa})\end{array}$ & $\begin{array}{c}\text { Ductility } \\
(\%)\end{array}$ \\
\hline DC01 & 235 & 318.5 & 28 \\
\hline PNO4 & 425.6 & 491.3 & 12.9 \\
\hline
\end{tabular}

\subsection{Microhardness measurement}

The microhardness measurement according to Vickers (HV0.1) was carried out on Buehler IndentaMet 110 series equipment. Measurements were realised according to STN EN ISO 6507-1:2006-06 standard. The measurement results of DC01 steel sheets treated by PLASOX process, measured in the material thickness direction are documented in Fig. 3. The first measurement was performed in the depth of $15 \mu \mathrm{m}$ from the surface and the distance between two next indents was $80 \mu \mathrm{m}$. Microhardness of steel DC01 treated by PLASOX process in depth of $15 \mu \mathrm{m}$ was $190 \mathrm{HV} 0.1$. Microhardness of diffusion zone in depth of $500 \mu \mathrm{m}$ was $120 \mathrm{HV} 0.1$, the average mircohardness of DC01 base material was 106,3 HV0.1. The higher values of microhardness in case of treated material were caused by the presence of nitrides in whole material volume.

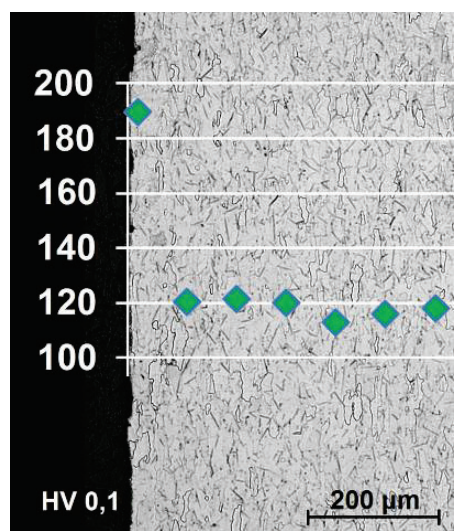

Figure 3 Microhardness measurement of PNO4 sample

\subsection{Erichsen cupping test}

The DC0.1 steel is primarily designed for deepdrawing forming operation in automotive industry. In order to determine the influence of significantly increased mechanical properties on deep-drawability of treated material, the Erichsen cupping test was carried out according to STN EN ISO 20482 standard. The test was performed on three individual samples of DC01 steel 
sheets before and after PLASOX process. The material is drawn during the test until the fracture on the surface occurs. The average depth of three indents measured in the Erichsen cupping test is documented in Tab. 3.

Table 3 Erichsen cupping test results

\begin{tabular}{|l|c|}
\hline \multicolumn{1}{|c|}{ Sample } & Average indent depth $(\mathrm{mm})$ \\
\hline DC01 & 10.71 \\
\hline PLASOX process & 9.76 \\
\hline
\end{tabular}

The results showed, that the depth of the indent decreased by $8.9 \%$ after PLASOX process in comparison to DC01 base material. Thermo-chemical treatment had negative effect on the deep drawability of steel sheets due to the nitrides present in the whole volume and not only near the surface layer of the material. Steel sheets after Erichsen cupping test are illustrated in Fig. 4.

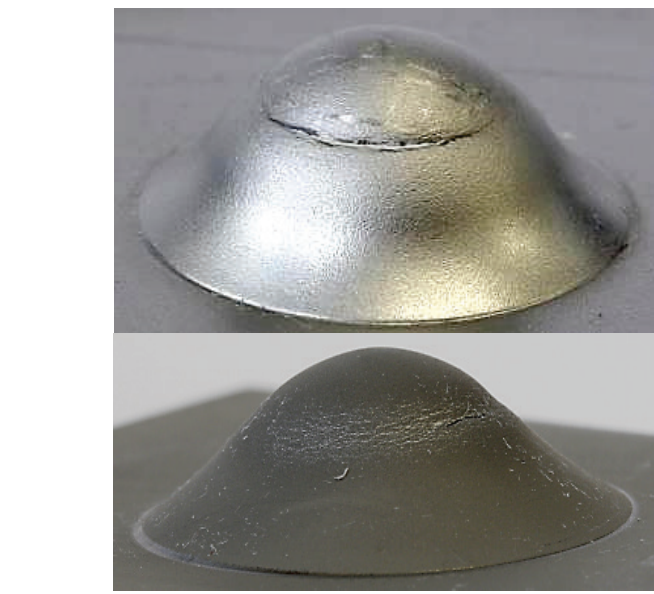

Figure 4 Erichsen cupping test: DC 01 (top) and PLASOX process (bottom)

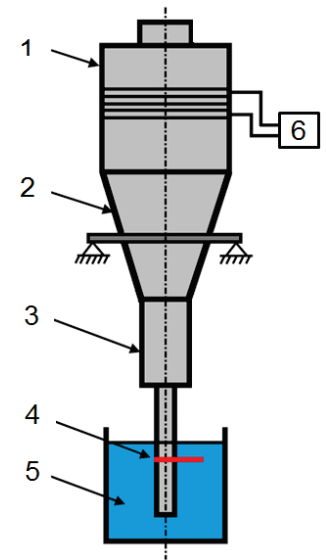

Figure 5 Scheme of KAUP-ŽU ultrasonic laboratory testing device (1 piezoceramic converter, 2 - booster, 3 - horn, 4 - specimen, 5 - coolant, 6 - ultrasonic generator)

\subsection{Fatigue life test}

Fatigue life tests were performed at the Faculty of Mechanical Engineering at the University of Žilina on the ultrasonic fatigue machine KAUP-ZU (Fig. 5) developed at the university. The fatigue experiments were done in condition of symmetric bending loads with frequency of $20 \mathrm{kHz}$ oscillation. All specimens were tested to the failure point. The shape and dimensions of specimens are illustrated in Fig. 6. Specimens were designed with regard to the high-frequency load requirements. All tests were performed at the room temperature $\left(20^{\circ} \mathrm{C}\right)$. To keep the constant temperature during the fatigue tests water cooling was used.

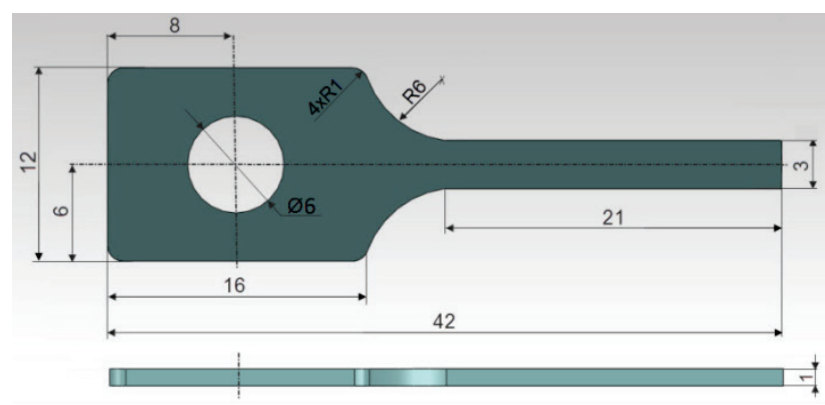

Figure 6 Shape and dimensions of a fatigue test specimen

Specimens without treatment as well as specimens treated by PLASOX process were welded by TruFiber 400 laser (Fig. 7). Parameters of welding are given in Tab. 4.

Table 4 Welding parameters

\begin{tabular}{|l|c|c|}
\hline \multicolumn{1}{|c|}{ Parameters } & DC01 & PLASOX \\
\hline Power $(\mathrm{W})$ & 295 & 315 \\
\hline Spot size $(\mu \mathrm{m})$ & 13 & 13 \\
\hline Welding speed $(\mathrm{mm} / \mathrm{s})$ & 9 & 10 \\
\hline Shielding gas / gas flow $(1 / \mathrm{min})$ & $\mathrm{Ar} / 7$ & $\mathrm{Ar} / 9$ \\
\hline
\end{tabular}

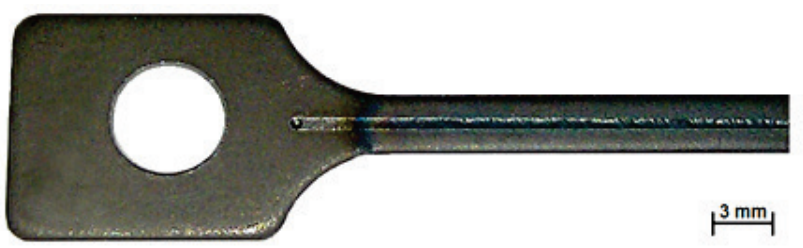

Figure 7 Testing specimen after welding

The macrostructure of weld joint of steel sheet without treatment as well as treated by nitrooxidation (Fig. 8) did not show any abnormalities in weld shape or any defects. Previous research made by LBW using disk laser with laser spot size of 400 microns showed a lot of porosity and affected whole volume of the specimen. The application of very small laser spot size brought massive improvement in weld joint shape as well as the appearance of the surface and root section of the weld joint.

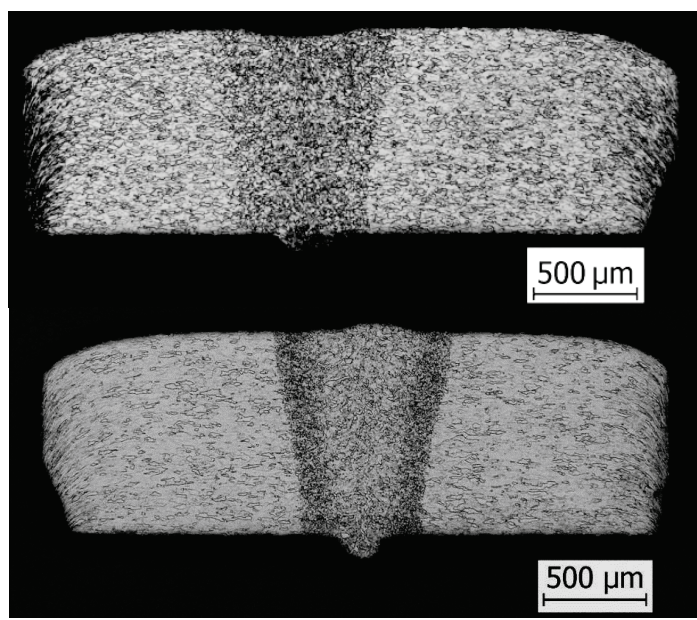

Figure 8 Macrostructure of weld joint of non-treated (top) and PLASOX treated (bottom) specimens 
The weld metal width in case of non-treated material was approximately $590 \mu \mathrm{m}$ near the surface whereas in root section it was $360 \mu \mathrm{m}$. The weld metal width of treated sample near the surface was approx. $540 \mu \mathrm{m}$ and in the root part of the weld approx. $310 \mu \mathrm{m}$. Porosity and other defects were not observed in weld joints of treated and non-treated materials.

The results of the fatigue life tests are referred to in the form of $S-N$ curves, which represents the stress amplitude $\sigma_{\mathrm{a}}$ in dependence on the number of cycles to failure $N_{\mathrm{f}}$. All the measurements were done in the interval of the stress amplitude $\sigma_{\mathrm{a}}=(280 \div 80) \mathrm{MPa}$. The obtained values are documented in Fig. 9. Graph shows the fatigue properties of the weld joints of steel sheets before and after PLASOX process and fatigue properties of steel sheets DC01 before and after PLASOX process without weld.

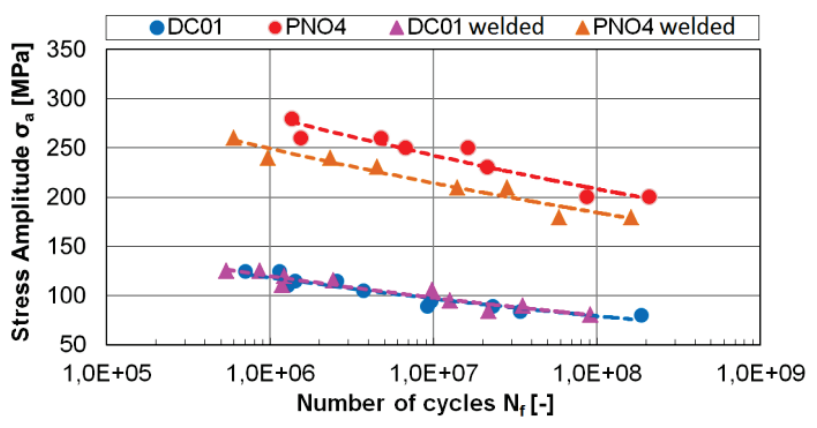

Figure 9 Fatigue life test results

The results proved that the fatigue life of the thin steel sheets treated by PLASOX process containing welds was higher in comparison to those without surface treatment with weld. The fatigue curves of steel sheets before and after nitrooxidation process, as well as weld joints of steel sheets before and after nitrooxidation process have a similar shape.

The fatigue life strength $\left(\sigma_{\mathrm{c} 10}^{8}\right)$ was determined from the $S$ - $N$ curves shown in Fig. 9 as nominal value of the $N_{\mathrm{f}}$ $=10^{8}$ cycles to fracture. Obtained values are given in Table 4.

Table 4 Fatigue life strength test results

\begin{tabular}{|l|c|}
\hline \multicolumn{1}{|c|}{ Sample } & $\sigma_{\mathrm{c} 10}(\mathrm{MPa})$ \\
\hline DC01 & 80 \\
\hline DC01 welded & 80 \\
\hline PLASOX & 210 \\
\hline PLASOX welded & 185 \\
\hline
\end{tabular}

The above table shows that the fatigue life strength of steel sheets treated by PLASOX process increased by $162.5 \%$ in comparison to DC01 base material. Fatigue life strength of steel sheets treated by PLASOX process decreased after welding above $12 \%$ in comparison to steel sheets treated by PLASOX process without weld. The decrease was caused by the degradation of surface layer as well as the microstructural changes in weld metal and HAZ, where nitrides were not observed.

\subsection{Fractographic analysis}

Fractographic analysis of fractured surfaces (Fig. 10) proved that the fatigue cracks in the case of weld joints of steel sheets DC01, as well as the steel sheets DC01 without weld initiated mostly simultaneously from top and bottom side of steel sheets. Initiated cracks were propagating by transcrystalline fatigue mechanism to the centre of the steel sheet thickness, whereas the remaining part of sheet cross-section was broken by the ductile fracture with characteristic pitting morphology. The fatigue cracks had the transgranular character. On the fractured areas the striation fields were observed.

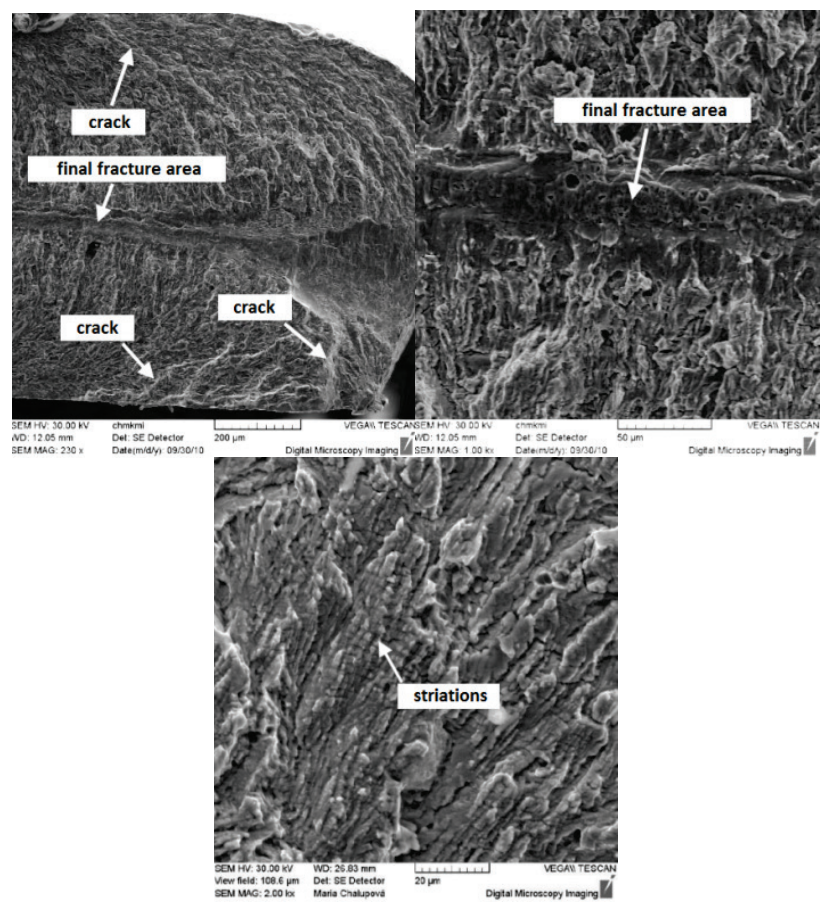

Figure 10 Fractographic analysis of DC 01 material without treatment

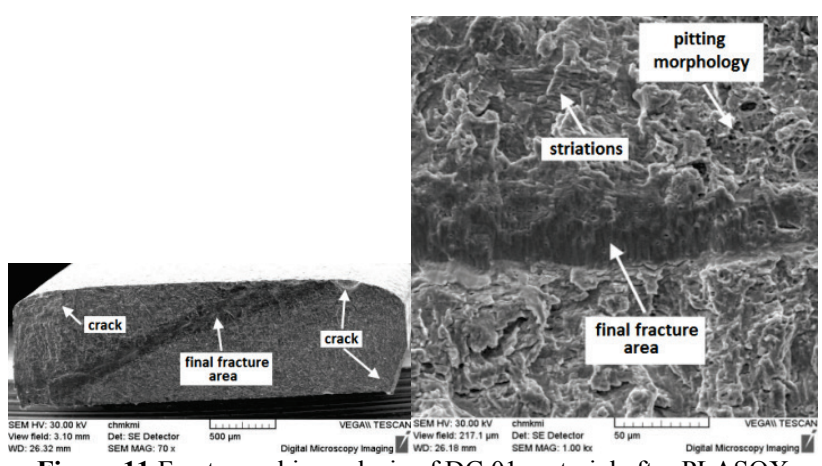

Figure 11 Fractographic analysis of DC 01 material after PLASOX treatment

In the case of weld joints of steel sheets treated by PLASOX process, as well as steel sheets treated by PLASOX process without weld joints (Fig. 11), multiple fatigue crack initiation was observed. Cracks were initiated mostly from corner edge of steel sheets as well as from the specimen surface. The transcrystalline fatigue character mechanism of the fracture was observed similar to DC01 base material. Character of final fracture was also transcrystalline with pitting morphology. Further research should also involve the influence of weld width and shape on fracture behaviour [9].

\section{Conclusion}

Thermo-chemical treatment by PLASOX process had a positive effect on fatigue life strength of thin steel sheets 
DC01, as well as weld joint of steel sheets treated by PLASOX process. Fatigue life strength of weld joints of steel sheets treated by nitrooxidation increased by $131 \%$ in comparison to DC01 base material without weld. It can be due to the nitrooxidic layer that particularly prolonged the fatigue initiation period and therefore the overall fatigue life. By the fractography, only transcrystalline fatigue character mechanism and ductile type of the fracture were observed.

\section{Acknowledgement}

This paper was supported by scientific grant agency of the Ministry of education of Slovak republic (project VEGA No.1/0470/14).

\section{References}

[1] Varga, V.; Viňáš, J. Laser beam welding of coated thin steel sheets. // Technológia 2001, Proceedings of $7^{\text {th }}$ International Conference / Bratislava, 2001. pp. 659-662, ISBN 80-227-1567-0

[2] Marônek, M.; Bárta, J. Palček, P.; Ulrich, K. Fatigue properties of steel sheets treated by nitrooxidation. // World Academy of Science, Engineering and Technology. 7, 77(2011), pp. 291-296.

[3] Nový, F.; Cincala, M.; Kopas, P.; Bokuvka, O. Mechanisms of high-strength structural material fatigue failure in ultrawide life region. // Materials Science \& Engineering / A. 462, 1-2(2007), pp. 189-192. https://doi.org/10.1016/j.msea.2006.03.147

[4] Michalec, I.; Bárta, J.; Jančár, J.; Bártová, K.; Marônek, M. Metallurgical joining of steel sheets treated by nitrooxidation by a hybrid CMT - laser process. // METAL 2011: 20. jubilejní ročník mezinárodní konference metalurgie a materiálů / Brno, 2011.

[5] Dománková, M.; Kebísková, J.; Repková, T.; Lazar, R.; Kusý, M. Influence of nitridation and nitrooxidation processes on microstructure and corrosion properties of low carbon deep-drawing steels. // Materials Science and Technology https://www.mtf.stuba.sk/docs/internetovy_ casopis/2011/1/PDF/kebiskova.pdf, 11, 1(2011), pp. 40-51.

[6] Marônek, M.; Bárta, J.; Bártová, K.; Dř́ímal, D. Welding of steel sheets treated by nitrooxidation. // JOM-16: $16^{\text {th }}$ International Conference on the Joining of Materials $\& 7^{\text {th }}$ International Conference on Education in Welding ICEW-7 / Tisvildeleje, 2011.

[7] Kozlík, P. The fatigue characteristics of weld joints of steel sheets treated by nitrooxidation. // Slovak University of Technology, Faculty of Materials Science and Technology, Diploma Thesis, 2011

[8] Kozak, D.; Samardzic, I.; Konjatic, P. Fracture mechanics parameters estimation of CCT specimens made of X 5 CrNi 1810 steel. // Metalurgija. 48, 2(2009), pp. 79-82.

[9] Konjatic, P.; Kozak, D.; Gubeljak, N. The influence of the weld width on fracture behaviour of the heterogeneous welded joint. // Advances in fracture and damage mechanics X. 488-489, (2012), pp. 367-370.

\section{Authors' addresses}

Jozef Bárta, Ing. PhD.

Slovak University of Technology in Bratislava, Faculty of Materials Science and Technology in Trnava

Paulínska 16, 91724 Trnava, Slovakia

jozef.barta@stuba.sk

Milan Maronek, Prof. Ing. PhD.

Slovak University of Technology in Bratislava, Faculty of Materials Science and Technology in Trnava Paulínska 16, 91724 Trnava, Slovakia milan.maronek@stuba.sk

Jaroslav Jančár, Ing. PhD.

Slovak University of Technology in Bratislava, Faculty of Materials Science and Technology in Trnava Paulínska 16, 91724 Trnava, Slovakia jaroslav.jancar@stuba.sk

Peter Krampot'ák, Ing. PhD.

Slovak University of Technology in Bratislava, Faculty of Materials Science and Technology in Trnava Paulínska 16, 91724 Trnava, Slovakia peter.krampotak@stuba.sk

Františsek Nový, Ing. PhD.

The University of Zilina, Faculty of Mechanical Engineering Univerzitná 1, 01026 Žilina, Slovakia frantisek.novy@fstroj.uniza.sk

Ivan Samardžić, Prof. dr. sc.

J. J. Strossmayer University of Osijek

Faculty of Mechanical Engineering Slavonski Brod Trg Ivane Brlić Mažuranić 2, 35000 Slavonski Brod, Croatia ivan.samardzic@sfsb.hr 